\title{
Insulin-like growth factor axis in pregnancies affected by fetal growth disorders
}

\author{
Aamod R. Nawathe ${ }^{1,2}$, Mark Christian³ ${ }^{3}$ Sung Hye Kim², Mark Johnson ${ }^{1,2}$, Makrina D. Savvidou, ${ }^{1,2}$ \\ and Vasso Terzidou ${ }^{1,2^{*}}$ (D)
}

\begin{abstract}
Background: Insulin-like growth factors 1 and 2 (IGF1 and IGF2) and their binding proteins (IGFBPs) are expressed in the placenta and known to regulate fetal growth. DNA methylation is an epigenetic mechanism which involves addition of methyl group to a cytosine base in the DNA forming a methylated cytosine-phosphate-guanine (CpG) dinucleotide which is known to silence gene expression. This silences gene expression, potentially altering the expression of IGFs and their binding proteins. This study investigates the relationship between DNA methylation of components of the IGF axis in the placenta and disorders in fetal growth. Placental samples were obtained from cord insertions immediately after delivery from appropriate, small (defined as birthweight $<10$ th percentile for the gestation [SGA]) and macrosomic (defined as birthweight > the 90th percentile for the gestation [LGA]) neonates. Placental DNA methylation, mRNA expression and protein levels of components of the IGF axis were determined by pyrosequencing, rtPCR and Western blotting.
\end{abstract}

Results: In the placenta from small for gestational age (SGA) neonates $(n=16)$, mRNA and protein levels of IGF1 were lower and of IGFBPs $(1,2,3,4$ and 7$)$ were higher $(p<0.05)$ compared to appropriately grown neonates $(n=37)$. In contrast, in the placenta from large for gestational age (LGA) neonates $(n=20)$, mRNA and protein levels of IGF1 was not different and those of IGFBPs $(1,2,3$ and 4$)$ were lower $(p<0.05)$ compared to appropriately grown neonates. Compared to appropriately grown neonates, CpG methylation of the promoter regions of IGF1 was higher in SGA neonates. The CpG methylation of the promoter regions of IGFBP1, IGFBP2, IGFBP3, IGFBP4 and IGFBP7 was lower in the placenta from SGA neonates as compared to appropriately grown neonates, but was unchanged in the placenta from LGA neonates.

Conclusions: Our results suggest that changes in $\mathrm{CpG}$ methylation contribute to the changes in gene expression of components of the IGF axis in fetal growth disorders. Differential methylation of the IGF1 gene and its binding proteins is likely to play a role in the pathogenesis of SGA neonates.

Keywords: Insulin growth factor, Small fetus, Large fetus, Placental expression, DNA methylation

\section{Background}

Insulin-like growth factors 1 and 2 (IGF1, IGF2) are expressed in the placenta and are known to regulate fetal growth [1]. While maternal IGF1 has been shown to stimulate fetal growth by increasing the transfer of nutrients to the fetus [2], fetal IGF1 is presumed to stimulate

\footnotetext{
* Correspondence: v.terzidou@imperial.ac.uk

${ }^{1}$ Imperial College London, London, UK

${ }^{2}$ Academic Department of Obstetrics and Gynaecology, Chelsea and

Westminster Hospital, London, UK

Full list of author information is available at the end of the article
}

fetal growth by promoting anabolic events and DNA synthesis [3]. IGF1 gene ablation has been shown to reduce fetal weight while IGF1 administration has been shown to increase fetal weight [4]. The main role of IGF2 appears to be mediated through its effects on cellular growth and tissue-specific cell proliferation [5]. IGF2 overexpression in mice causes placental and fetal overgrowth, whereas IGF2 gene deletion reduces placental and fetal weight $[6,7]$. When both genes are deleted simultaneously, the effects on fetal growth are additive [8]. Studies on placental IGF1 
and IGF2 expression in growth-restricted fetuses are inconsistent [9-16]. The bioavailability of IGFs is modulated by their seven binding proteins (IGFBP) [17]. The affinity of IGFBP3 for IGFs is higher than other IGFBPs [18], hence approximately $80-90 \%$ of IGFs are bound to IGFBP3 [19]. In pregnancy, the IGFBPs and in particular IGFBP2, 3, 4 and 5, but not IGFBP1, are cleaved by proteases, which reduce their affinity for IGFs [20, 21]. As a result, the levels of maternal IGFBP1 continue to increase during pregnancy in a similar fashion to those of IGF1 [22]. Although IGFBP3 is the most common binding protein found in the placenta [23], IGF1 and IGFBP1 appear to play the major role in regulating fetal growth. IGFBP1 affinity towards IGF1 is three times higher than proteolyzed IGFBP3, but is lower for IGF2 [19]. Hence, the increased activity of proteases during pregnancy shifts the control of IGF action from IGFBP3 to IGFBP1.

Placental methylation is significantly lower compared to other somatic tissues [24-26] and this has been associated with promoting fetal development throughout gestation [27-30]. Placental function and the intrauterine environment play critical roles in fetal programming [31-33], and different lines of evidence suggest a role for epigenetic mechanisms, including genomic imprinting and DNA methylation in this process [34, 35]. Several animal models have also suggested that altering placental DNA methylation plays an important role in placental and fetal growth [36].

The aim of the current study was to investigate the genetic and epigenetic changes in placental IGF1/IGF2 and their seven binding proteins in order to understand the "net IGF bioavailability" in pregnancies with small for gestational age (SGA), large for gestational age (LGA) and appropriately grown neonates.

\section{Results}

\section{Maternal and neonatal characteristics}

Seventy-four women were recruited to the study, with appropriately grown $(n=38)$, SGA $(n=16)$ and LGA $(n=$ $20)$ neonates. The placental mRNA and protein expression was analysed in all cases. DNA methylation levels were analysed in a total of 24 women ( 8 in each group). The maternal and pregnancy characteristics of the study participants are given in Table 1. Compared to appropriately grown neonates, women with SGA neonates were delivered earlier, and women with LGA neonates had a higher BMI (Table 1).

\section{Placental mRNA expression and protein expression of the IGF axis and its binding proteins}

Compared to appropriately grown neonates, the placental mRNA expression of IGF1 was reduced in the SGA group but not in the LGA group (Fig. 1). There were no significant differences in IGF2 gene expression between the groups. Compared to appropriately grown neonates, the IGFBP1, 2, 3, and 4 gene expression was significantly higher in the SGA group $(p<0.001)$ and lower in the LGA group $(p<0.05)$. IGFBP5 and IGFBP6 expression was not detected in the placenta samples. IGFBP7 expression was higher in SGA group $(p<0.001)$ and not

Table 1 Maternal and pregnancy characteristics

\begin{tabular}{|c|c|c|c|c|}
\hline Variables & $\begin{array}{l}\text { Appropriately grown } \\
(n=38)\end{array}$ & $\begin{array}{l}\text { Small for gestational age } \\
(n=16)\end{array}$ & $\begin{array}{l}\text { Large for gestational age } \\
(n=20)\end{array}$ & $p$ value (overall) \\
\hline Maternal age (years) & $31.5(28.7-35.0)$ & $31.5(25.2-33.7)$ & $33.0(30.0-37.2)$ & 0.173 \\
\hline \multicolumn{5}{|l|}{ Parity, $n$ (\%) } \\
\hline Nulliparous, $n(\%)$ & $20(52.6)$ & $10(62.5)$ & $11(55.0)$ & \multirow[t]{2}{*}{0.8} \\
\hline Parous, $n(\%)$ & $18(47.4)$ & $6(37.5)$ & $9(45.0)$ & \\
\hline \multicolumn{5}{|l|}{ Racial origin } \\
\hline Caucasian, $n$ (\%) & $25(65.8)$ & $11(68.8)$ & $19(95.0)$ & \multirow[t]{3}{*}{0.045} \\
\hline Black, $n(\%)$ & $7(18.4)$ & $3(18.8)$ & $1(5.0)$ & \\
\hline Other, (\%) & $6(15.8)$ & $2(12.4)$ & $0(0)$ & \\
\hline Smokers, n (\%) & $1(2.6)$ & $2(12.5)$ & $1(5)$ & 0.341 \\
\hline Maternal body mass index at booking & $23.0(20.0-25.2)$ & $22.0(20.2-24.0)$ & $26.5(23.2-36.0)^{*}$ & 0.002 \\
\hline Gestational age at delivery (weeks) & $39.2(39.0-41.0)$ & $36.5(32.2-38.8)^{*}$ & $39.5(39.0-40.0)$ & 0.001 \\
\hline Maternal age (years) & $31.5(28.7-35.0)$ & $31.5(25.2-33.7)$ & $33.0(30.0-37.2)$ & 0.173 \\
\hline \multicolumn{5}{|l|}{ Parity, $n(\%)$} \\
\hline Nulliparous, $n(\%)$ & $20(52.6)$ & $10(62.5)$ & $11(55.0)$ & \multirow[t]{2}{*}{0.8} \\
\hline Parous, $n(\%)$ & $18(47.4)$ & $6(37.5)$ & $9(45.0)$ & \\
\hline Birthweight percentile & $54.5(21.0-76.2)$ & $1.4(0.3-6.8)^{*}$ & $98.3(95.2-99.6)^{*}$ & $<0.001$ \\
\hline
\end{tabular}

Data are expressed as median (interquartile range). Comparisons between categorical and continuous variables were done by $x^{2}$ or Fisher's exact test and MannWhitney test both with post hoc Bonferroni correction. ${ }^{*} p<0.01$ for comparisons vs. appropriately grown neonates 
a

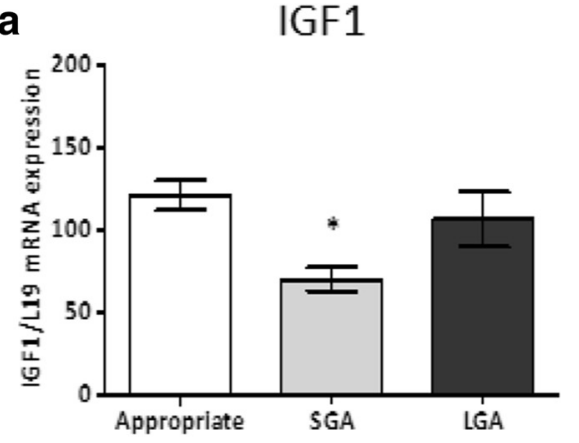

b

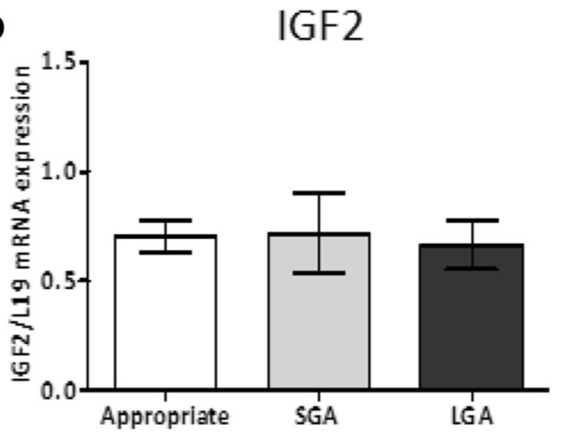

C

IGFBP1

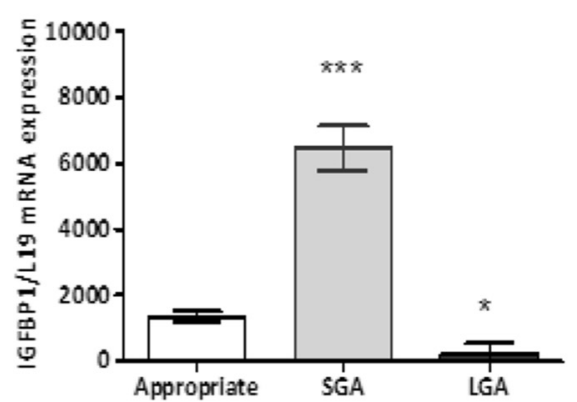

d

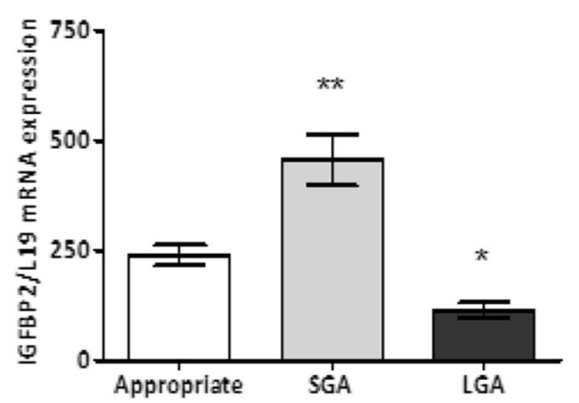

e

IGFBP3

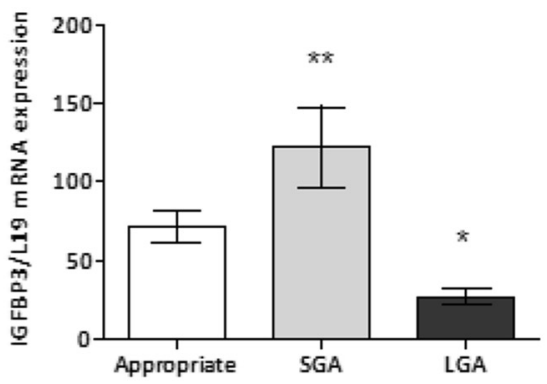

f

IGFBP4

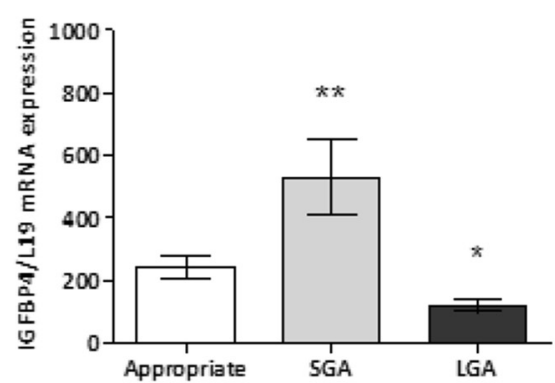

g

IGFBP7
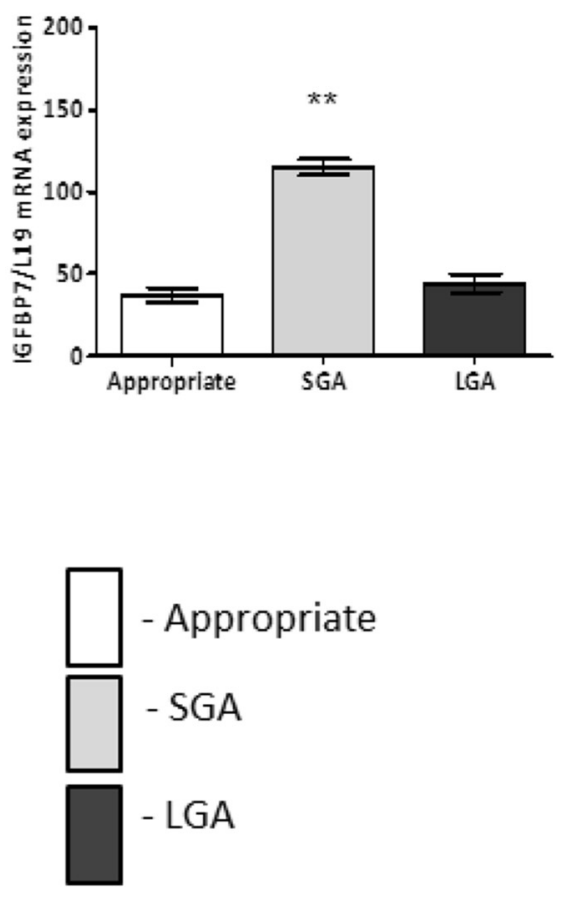

Fig. 1 Placental mRNA expression of the IGF axis in appropriately grown, SGA and LGA neonates. a IGF1 expression, b IGF2 expression, c IGFBP1 expression, d IGFBP2 expression, e IGFBP3 expression, $\mathbf{f}$ IGFBP4 expression, g IGFBP7 expression. ${ }^{*} p<0.05$, ${ }^{* *} p<0.005$, ${ }^{* * *} p<0.0005$ when compared to appropriately grown neonates; SGA small for gestational age, LGA large for gestational age 
different in the LGA group, compared to appropriately grown neonates. The mRNA expression of IGF1 was positively correlated with birthweight centiles $(r=0.22, p=$ 0.04) (Fig. 2). Conversely, there was a significant negative correlation between all the binding protein gene expression and birthweight percentiles (Fig. 2).

Western blotting revealed a correlation between placental protein expression and changes seen in the mRNA expression. Compared to appropriately grown neonates, there was a tendency for a lower placental IGF1 protein in SGA group (Fig. 3a). The protein content of IGFBP2, IGFBP3, IGFBP4 and IGFBP7 genes was significantly higher in SGA group (IGFBP2, $p<0.005$; IGFBP3, $p<$ 0.05 ; IGFBP4, $p<0.05$; IGFBP7, $p<0.05$ ) while that of IGFBP1, IGFBP2, IGFBP3 and IGFBP4 was lower in the LGA group (IGFBP1, $p<0.05$; IGFBP2, $p<0.005$; IGFBP3, $p<0.005$; IGFBP4, $p<0.0005$ ) (Fig. 3 ), compared to appropriately grown neonates.

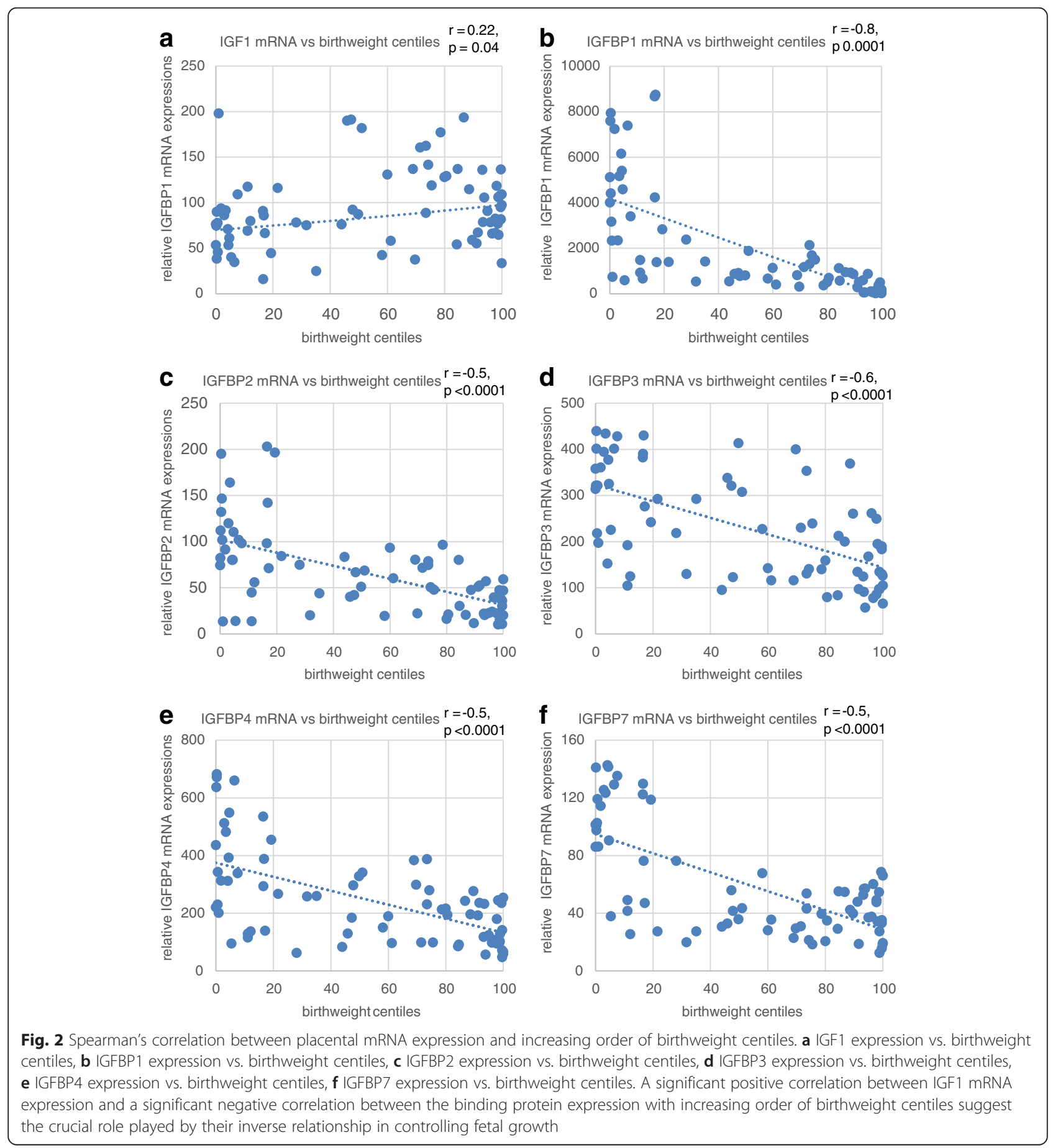




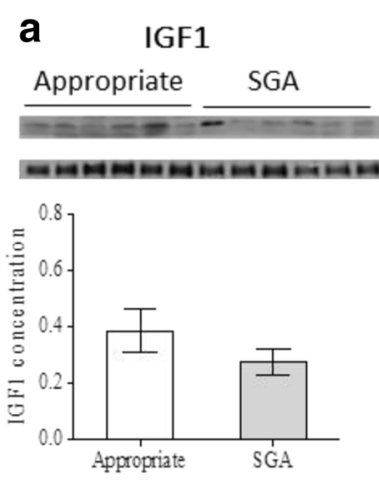

b

C

IGFBP2

d IGFBP3
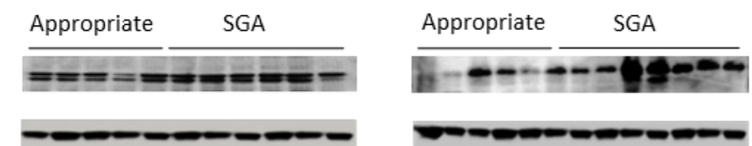

Appropriate SGA
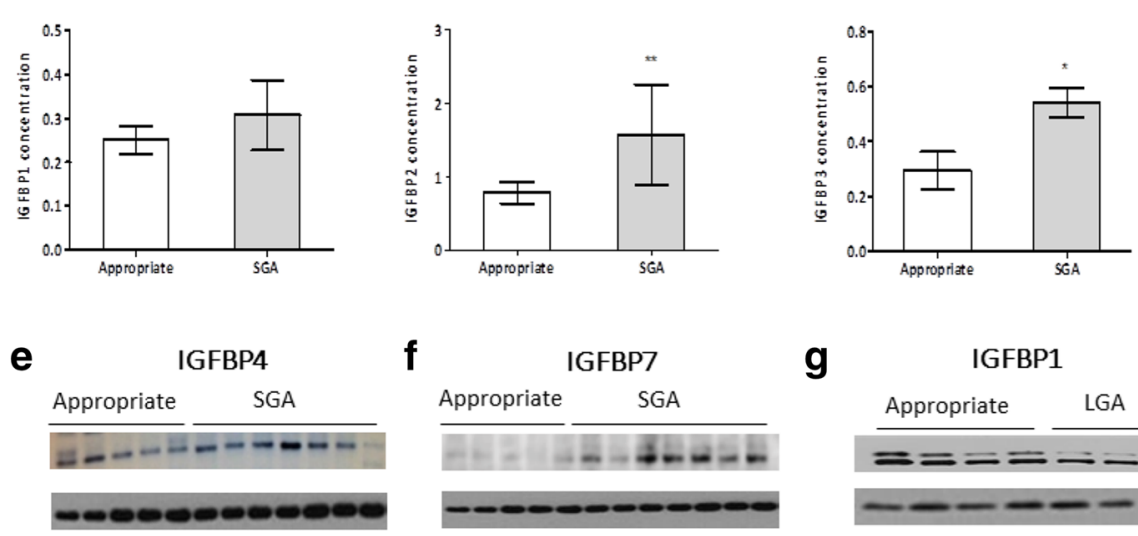

g

IGFBP1
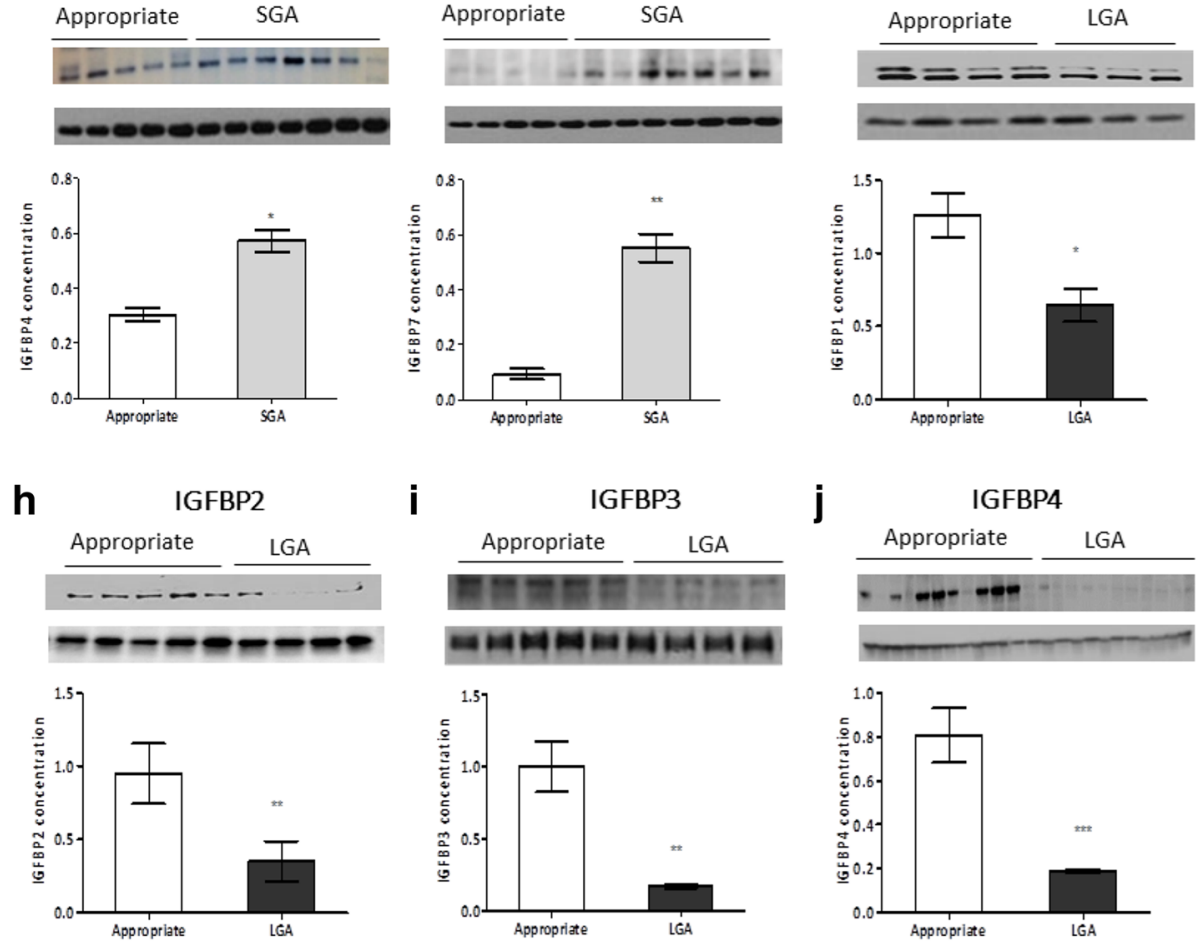

Fig. 3 (See legend on next page.)

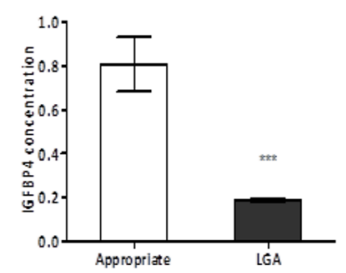


(See figure on previous page.)

Fig. 3 Placental protein expression of the IGF axis in appropriately grown, SGA and LGA neonates. a IGF1 expression, b IGFBP1 expression, c IGFBP2 expression, d IGFBP3 expression, e IGFBP4 expression, $\mathbf{f}$ IGFBP7 expression, $\mathbf{g}$ IGFBP1 expression, $\mathbf{h}$ IGFBP2 expression, $\mathbf{i}$ IGFBP3 expression, j IGFBP4 expression. ${ }^{*} p<0.05,{ }^{* *} p<0.005,{ }^{* * *} p<0.0005$, when compared to appropriately grown neonates. SGA small for gestational age, LGA large for gestational age. Increased protein expression of IGFBP1, IGFBP2, IGFBP3, IGFBP4 and IGFBP7 in SGAs and decreased expression of IGFBP1, IGFBP2, IGFBP3 and IGFBP4 in LGA neonates suggest inverse relationship of the binding protein expression with fetal growth

\section{Promoter CpG methylation of the IGF axis and its binding} proteins

In the SGA group, all CpG sites at the IGF1 promoter were found to be about 1.5 times hypermethylated as compared to appropriately grown neonates (Fig. 4). Conversely, the three CpG sites at the IGFBP1 and IGFBP2 promoters were found to be about half as methylated as the appropriately grown neonates, but there were no methylation differences in the LGA group. The CpG sites in the IGFBP3 promoter at positions 46,47 and 50 were also significantly hypomethylated in the SGA with no differences in the LGA group (Fig. 4). However, there were no methylation differences at sites 48 and 49 in the IGFBP3 promoter across all the groups. CpG sites 23, 24, 26, 27 and 28 but not 25 and 29 in the IGFBP4 promoter and sites 9 and 10 in the IGFBP7 promoter were significantly hypomethylated in the SGA group, compared to appropriately grown neonates, while there were no methylation differences in the LGA group (Fig. 4). The majority of CpG sites on the IGF1 promoter had a

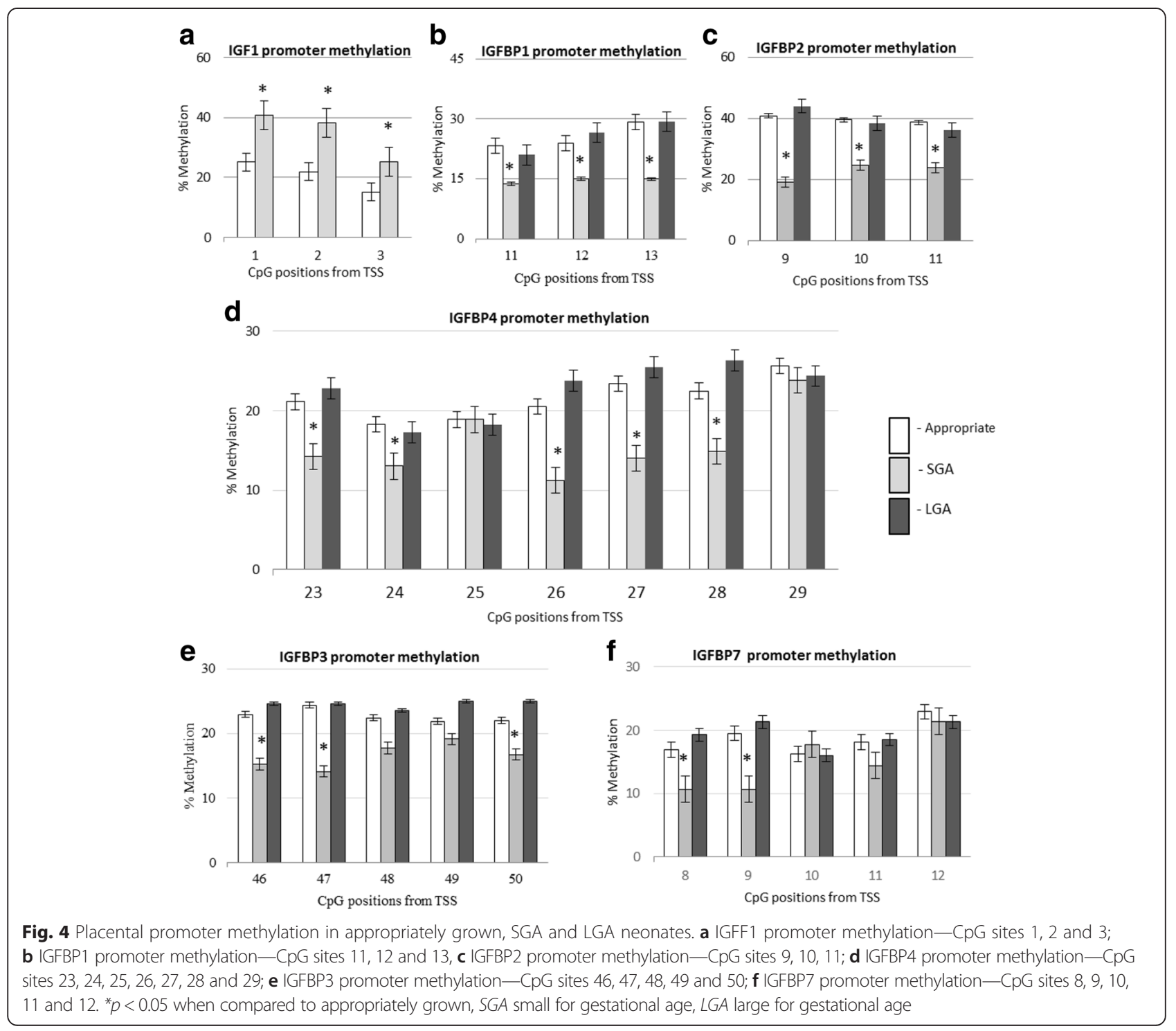


significant negative correlation with IGF1 mRNA expression (CpG 1, $r=-0.6, p=0.007$; CpG 2, $r=-0.73$, $p=0.0007 ;$ CpG 3, $r=-0.4, p=0.14$ ) (Table 2). In addition, the majority of the CpG sites on the promoters of the binding proteins IGFBP1, IGFBP2 and IGFBP3, CpG sites 23, 26, 27, 28 and 29 on the IGFBP4 and CpG sites 8 and 9 on the IGFBP7 promoter had a significant negative correlation with their respective mRNA expression (Table 2). No significant correlation with their respective mRNA expression was identified between CpG sites 24 and 25 of IGFBP4 promoter and sites 10, 11 and 12 of IGFBP7 promoter. Birthweight centiles had a significant negative correlation with IGF1 promoter methylation but a significant positive correlation with binding protein methylation (Fig. 5).

Table 2 Correlation between DNA methylation and mRNA expression

\begin{tabular}{|c|c|c|c|c|}
\hline Gene & CpG number & CpG location & Rs & $p$ value \\
\hline IGF1 & 1 & Chr12:-102874567 & -0.6275 & $0.007^{*}$ \\
\hline IGF1 & 2 & Chr12: -102874689 & -0.7377 & $0.0007^{*}$ \\
\hline IGF1 & 3 & Chr12: -102874755 & -0.4044 & 0.10 \\
\hline |GFBP1 & 11 & Chr7: 45927583 & -0.4728 & $0.01^{*}$ \\
\hline IGFBP1 & 12 & Chr7: 45927579 & -0.6349 & $0.0005^{*}$ \\
\hline IGFBP1 & 13 & Chr7: 45927575 & -0.7005 & $<0.0001^{*}$ \\
\hline IGFBP2 & 9 & Chr2: 217497928 & -0.7785 & $<0.0001^{*}$ \\
\hline IGFBP2 & 10 & Chr2: 217497846 & -0.5856 & $0.001^{*}$ \\
\hline IGFBP2 & 11 & Chr2: 217497740 & -0.6205 & $0.0007^{*}$ \\
\hline IGFBP3 & 46 & Chr7: -45960433 & -0.8086 & $<0.0001^{*}$ \\
\hline IGFBP3 & 47 & Chr7: -45960418 & -0.6627 & $0.0002^{*}$ \\
\hline IGFBP3 & 48 & Chr7: -45960415 & -0.5104 & $0.007^{*}$ \\
\hline IGFBP3 & 49 & Chr7: -45960400 & -0.4161 & $0.04^{*}$ \\
\hline IGFBP3 & 50 & Chr7: -45960394 & -0.6306 & $0.001^{*}$ \\
\hline IGFBP4 & 23 & Chr17: 38599317 & -0.5971 & $0.002^{*}$ \\
\hline IGFBP4 & 24 & Chr17: 38599314 & -0.3923 & 0.05 \\
\hline IGFBP4 & 25 & Chr17: 38599311 & 0.04471 & 0.83 \\
\hline IGFBP4 & 26 & Chr17: 38599308 & -0.6726 & $0.0003^{*}$ \\
\hline IGFBP4 & 27 & Chr17: 38599305 & 0.626 & $0.001^{*}$ \\
\hline IGFBP4 & 28 & Chr17: 38599302 & -0.5158 & $0.009^{*}$ \\
\hline IGFBP4 & 29 & Chr17: 38599299 & -0.1613 & $0.45^{*}$ \\
\hline IGFBP7 & 8 & Chr4: -57976141 & -0.6501 & $0.0006^{*}$ \\
\hline IGFBP7 & 9 & Chr4: -57976145 & -0.6882 & $0.0002^{*}$ \\
\hline IGFBP7 & 10 & Chr4: -57976152 & 0.19 & 0.37 \\
\hline IGFBP7 & 11 & Chr4: -57976157 & -0.2764 & 0.19 \\
\hline IGFBP7 & 12 & Chr4: -57976172 & -0.05846 & 0.78 \\
\hline
\end{tabular}

Spearman's correlation between mRNA expression and DNA methylation showed significant inverse correlation at all $\mathrm{CpGs}$ tested except in two locations (24 and 25) at IGFBP4 promoter region and at three locations $(10,11$ and 12) at IGFBP7 promoter region

\section{Discussion}

Our study has demonstrated that in pregnancies affected by SGA, the placental IGF and IGFBP axis is altered; we found that placental IGF1 mRNA is decreased, the IGFBPs expression is increased and these changes are associated with alterations in DNA methylation levels of IGF1 (hypermethylated) and IGFBPs (hypomethylated). These findings indicate that epigenetic modification may play a key role in controlling fetal growth. In contrast, in LGA pregnancies, the differences in gene expression could not be explained by corresponding changes in the methylation of the respective gene promoters.

Various reports have described differences in placental IGF and IGFBP mRNA expression in fetuses affected by growth disorders. However, these studies were limited by the small sample size, the number of binding proteins being investigated and the type of tissue being examined i.e. either the placenta $[10-12,37,38]$ or umbilical blood [39-41]. In our study, we have assessed the placental IGF axis at the epigenetic, transcriptional and translation levels in pregnancies resulting in appropriate, small and large neonates. The crucial role played by IGF1 in fetal growth and programming is supported by animal studies where IGF1 knockout mice not only had a reduced birthweight but also continued to weigh less throughout their lives [7]. We found IGF1 mRNA expression was lower in SGA group, which is consistent with previous studies [10, 26]. It is well known that altered DNA methylation can contribute to disease pathogenesis [42, 43]. Indeed, we found that the IGF1 gene promoter was hypermethylated in the placenta of SGA neonates. Importantly, IGF1 mRNA expression had a significant positive correlation with birthweight, while IGF1 promoter methylation had a significant negative correlation. These relationships between gene expression, promoter methylation and birthweight suggest that the epigenetic control of IGF1 expression has a causative role in the pathogenesis of fetal growth restriction. In agreement with other studies, we found that IGF1 was not differentially expressed in LGA neonates and IGF2 expression was similar across all the subgroups [44, 45].

We found elevated mRNA and protein levels of IGFBP1, IGFBP2, IGFBP3, IGFBP4 and IGFBP7 in placenta of SGA neonates and decreased expression of IGFBP1, IGFBP2, IGFBP3 and IGFBP4 in the LGA group. Corresponding to these changes in gene expression, the promoters of the respective genes were hypomethylated in the SGA. There was a significant negative correlation between IGFBPs 1 , 2, 3, 4 and 7 mRNA expression and birthweight while promoter methylation of all the binding proteins showed a significant positive correlation with it. While some studies have shown an inverse correlation of IGFBP1 and IGFBP2 with birthweight $[38,46]$, there are conflicting data regarding IGFBP3 gene expression and a paucity of data describing IGFBP4, IGFBP5, and IGFBP6 expression in the 

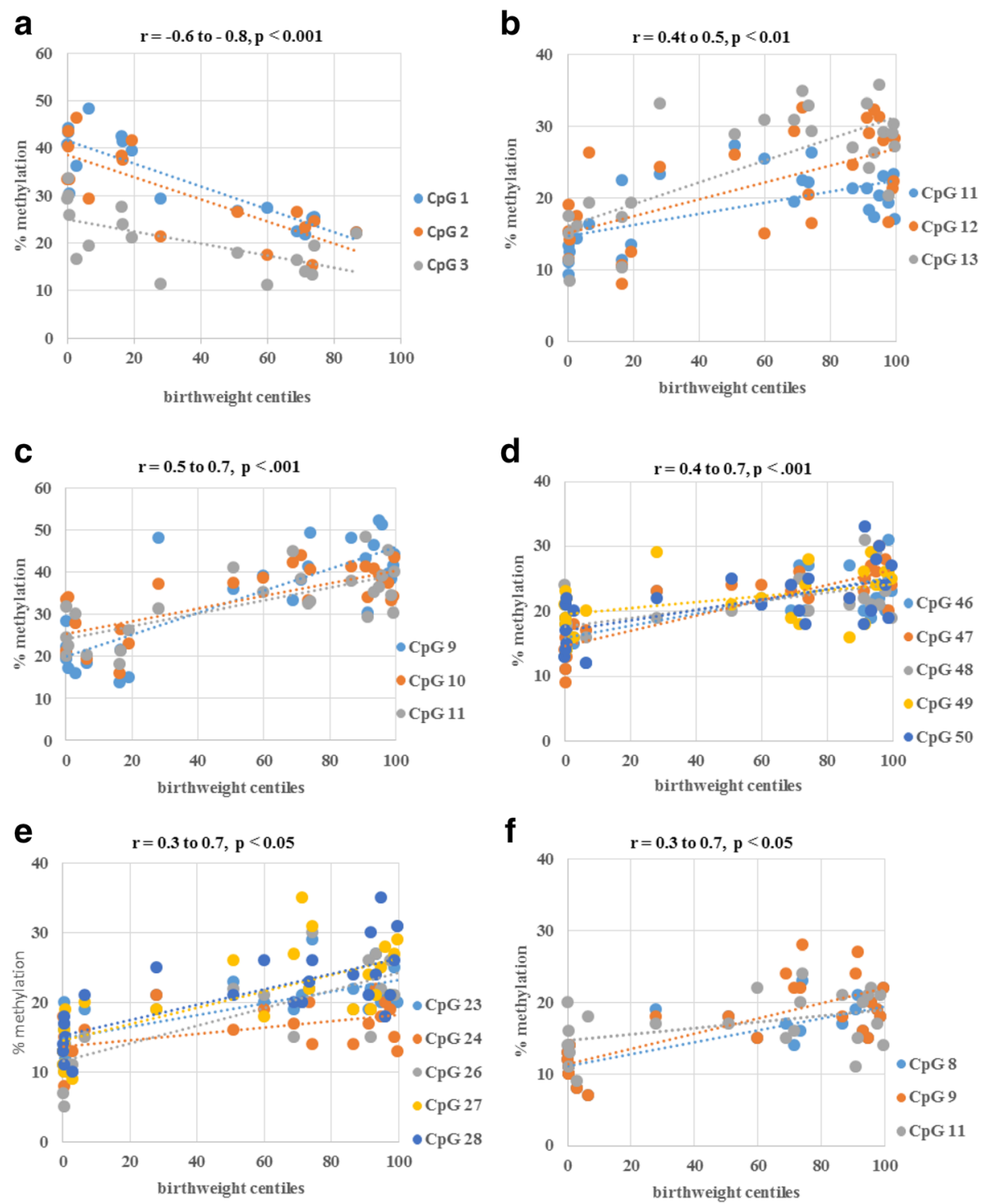

Fig. 5 Spearman's correlation between placental promoter CpG methylation and increasing order of birthweight centiles. a IGF1 methylation vs. birthweight centiles, b IGFBP1 methylation vs. birthweight centiles, c IGFBP2 methylation vs. birthweight centiles, d IGFBP3 methylation vs. birthweight centiles, e IGFBP4 methylation vs. birthweight centiles, $\mathbf{f}$ IGFBP7 methylation vs. birthweight centiles. A significant negative correlation between IGF1 mRNA expression and a significant positive correlation between the binding protein expression with increasing order of birthweight centiles could reflect the indirect role played by DNA methylation relationship in controlling fetal growth by controlling gene expression of the IGF axis

placenta of small or large neonates [39, 47, 48]. IGFBP5 and IGFBP6 could not be detected in our samples; this may be due to their expression being restricted to the decidua $[1,49]$. IGFBP7 gene expression has not been previously investigated in small or large neonates and has not been detected in human placenta. An inverse correlation between promoter methylation and mRNA expression suggests that DNA methylation plays a crucial role in the gene expression of the binding proteins and therefore impacting in the pathogenesis of small fetal size. There were no methylation differences in the promoters of IGF1 and the binding proteins in the LGA group. It is possible that DNA methylation plays an important role in the pathogenesis of small fetal size while other mechanisms, like microRNA or histone modifications, may be important in the pathogenesis of macrosomia.

Another modification of cytosine is called 5hydroxymethylcytosine (5-HMC) which is also known to play a role in activating or silencing genes [50]. Liu et al. have recently shown significant differences in 5-HMC concentrations in different tissues of the human body with the highest concentration (0.4-0.6\%) found in the brain, liver, kidney and colorectal tissues while lowest concentration $(0.02 \%)$ found in the placenta [51]. Piyasena et al. 
[52] have suggested that placental 5-methylcytocine and 5-hydroxythethylcytocine patterns are associated with the expression of imprinted genes linked with birthweight. Future work can investigate placental 5-HMC in the IGF system-related genes in appropriately grown, small and large neonates.

\section{Conclusions}

We have found that IGF1 gene is underexpressed and IGFBP1, IGFBP2, IGFBP3, IGFBP4 and IGFBP7 are overexpressed in the placenta of SGA neonates, and these differences could be partly explained by the inverse changes in promoter methylation. In contrast, placental IGFBP1, IGFBP2, IGFBP3 and IGFBP4 genes are underexpressed in pregnancies with LGA neonates, but these differences are not associated with changes in DNA methylation; further studies are required to identify the mechanisms responsible for their gene expression.

\section{Methods}

We obtained placental biopsies, immediately following delivery, from women that delivered appropriate size neonates, small for gestational age (SGA) neonates, defined as birthweight $<10$ th percentile for gestation, adjusted for gestational age, and large for gestational age (LGA) neonates, defined as birthweight $>90$ th percentile for gestation, adjusted for gestational age [53]. Placental samples were collected from the fetal side and washed with PBS to remove contaminants. Areas which appeared calcified or encored were excluded, and samples were stored at $-80{ }^{\circ} \mathrm{C}$ until further analysis. Umbilical cord tissue, amniotic membranes and decidua were excluded. All pregnancies were dated by a first trimester scan at 11-13 weeks of gestation. Booking maternal body mass index (BMI) was calculated as weight/height in square meter. All patients gave a written informed consent form, and the study was approved by the NRES Committee London-Central REC ref number: 11/LO/ 1315.

\section{RNA extraction, CDNA preparation and real-time PCR}

RNA extraction was performed using RNeasy Mini Kit (Qiagen, Germany). Any contaminating DNA was removed by DNaseI (Invitrogen) treatment room temperature for $15 \mathrm{~min}$, and complementary deoxyribonucleic acid (cDNA) was prepared by using the MMLV kit (Sigma ${ }^{\circ}$, Cat No. M1302) according to the manufacturer's instructions by reverse transcription of $1 \mu \mathrm{g}$ of RNA. The cDNA was stored at $-20{ }^{\circ} \mathrm{C}$ until further analysis. A $2 \mu \mathrm{l}$ of cDNA was added to $8 \mu \mathrm{l}$ of reaction mix to make a total of $10 \mu \mathrm{l}$ per well. The reaction mix consisted of $5 \mu \mathrm{l}$ of SYBR Green $\left\{\right.$ Sigma ${ }^{\circ}$, Cat No QR0100), $0.2 \mu \mathrm{l}$ of ROX Reference Dye (Sigma ${ }^{\text {, }}$ Cat No R4526), $300 \mathrm{nM}$ of each primer, and RNase free water to make up the remaining volume. All primers were optimised prior to cDNA amplification. Four such wells were cleaned up using the QIAquick PCR purification kit according to the manufacturer's instructions (Qiagen ${ }^{\circ}$ ). Serial dilutions from the purified DNA in the ratio of 1:10 were made which were then used in duplicate in the realtime PCR reactions for the respective gene. The steps of the quantification PCR included initial denaturation at $94^{\circ}$ $\mathrm{C}$ for $2 \mathrm{~min}$ following which samples were subjected to 40 amplification cycles comprising of denaturation at $95{ }^{\circ} \mathrm{C}$ for $15 \mathrm{~s}$, annealing and elongation of each gene for $60 \mathrm{~s}$. All the mRNA data was expressed as a relative quantification to the total amount of similarly expressed L19 gene. The results of the melt curve analysis were verified further by electrophoresis on $1 \%$ agarose gel and photographed on UV light illuminator (Clare Chemical Research). A negative control was included per gene in the reaction.

\section{Primers}

The primers were designed using the protein encoding transcripts from www.ensembl.org [54] and Primer3 (version 0.4.0) at http://frodo.wi.mit.edu/. All the primers were between 80 and $150 \mathrm{bp}$. The primers were checked using Primer-BLAST at http://blast.ncbi.nlm.nih.gov/ to ensure $100 \%$ maximum identification of the nucleotide sequences. The primers were IGF1F:5'-CAGCAGTCTTCC AACCCAT-3', IGF1R: 5'-ACAGCGCCAGGTAGAAGA G-3'; IGF2F:5' -CAATATGACACCACCGTGCT-3', IGF2 R:5'-GGACTGCTTCCAGGTGTCAT-3'; IGFBP1F:5'-CT GCCAAACTGCAACAAGAA-3', IGFBP1R:5'-GAGACC CAGGGATCCTCTTC-3'; IGFBP2F:5'-ATGGCGATGAC CATCAGA-3', IGFBP2R:5' -ACCTGGTCCAGTTCCTGT TG-3'; IGFBP3F:5' -CAGAGACTCGAGCACAGCAC-3', IGFBP3R:5'-GCCGCCTAAGTCACAAAGTC-3'; IGFBP4 F:5'-CCCACGAGGACCTCTACATC-3', IGFBP4R:5' -AT CCAGAGCTGGGTGACACT-3'; IGFBP5F:5'-AGCAGC AACGTTGAGTGATG-3'， IGFBP5R:5'-GATGAAATGA GTGGCGTCCT-3'; IGFBP6F:5' -GCTGTTGCAGAGGA GAATCC-3', IGFBP6R:5'-GGTAGAAGCCTCGATGGT CA; IGFBP7F:5' -CATCCAATTCCCAAGGACAG-3', IGF BP7R:5'-TATAGCTCGGCACCTTCACC-3'; L19F:5'-GC GGAAGGGTACAGCCAAT-3', L19R:5'-GCAGCCGGC GCAAA-3'.

\section{Protein extraction, western blot and immunodetection}

Placental samples were homogenised in modified RIPA buffer containing $1 \%$ Triton $\times 100,1 \%$ sodium deoxycholate, $0.1 \%$ SDS, $150 \mathrm{mM}$ sodium chloride, $10 \mathrm{mM}$ Tris (pH 7.4) and $1 \mathrm{mM}$ EDTA with $1 \mathrm{mM}$ of PMSF and protease inhibitor cocktail (Sigma-Aldrich) which was used to lyse the placental samples. The lysate was centrifuged at $13,000 \times g$ for $30 \mathrm{~min}$ at $4{ }^{\circ} \mathrm{C}$ and the supernatant extracted to obtain whole-cell protein. The protein extracts were quantified by the Lowry method (Bio-Rad). Protein samples were aliquoted and then stored at $-80{ }^{\circ} \mathrm{C}$ to avoid freeze-thaw 
cycles. Denaturation of proteins was performed at $80{ }^{\circ} \mathrm{C}$ for 10 min with loading dye consisting of $3 \%$ glycerol, $3 \%$ SDS, 1 \% Bromophenol blue and $\beta$-mercaptoethanol. Equal amount of proteins $(50 \mu \mathrm{g})$ were run either on a $10 \%$ SDSPolyacrylamide gel for $80 \mathrm{~min}$ at $120 \mathrm{~V}$, and were transferred to polyvinylidene difluoride (PVDF) membranes (Millipore) for $90 \mathrm{~min}$ at $300 \mathrm{~mA}$ or on a Bio-Rad Criterion TGX gel, 26-well midi gel (Cat No. 567-1085) for $80 \mathrm{~min}$ at $120 \mathrm{~V}$ and transferred for $7 \mathrm{~min}$ on a Tran-Blot ${ }^{\circ}$ Turbo $^{\text {Tx }}$ Midi PVDF Transfer Pack (Cat No. 170-4157). Membranes were incubated in $5 \%$ blocking buffer for $1 \mathrm{~h}$ at room temperature and hybridized with primary antibody overnight at $4{ }^{\circ} \mathrm{C}$. Secondary antibody incubation was then carried out the following day and immunodetection using ECL2 or ECL (Fisher Scientific). The primary antibodies were IGF1-Abcam, cat no. Ab9572; IGFBP1-Santa Cruz, cat no. Sc-55474, IGFBP2-Abcam, cat no. Ab109284;
IGFBP3-Santa Cruz, cat no. Sc-6004; IGFBP4-Santa Cruz, cat no. Sc-6005; IGFBP7-Santa Cruz, cat no. Sc13095; $\beta$-actin-Abcam, cat no. Ab6276; positive control-liver (human) tissue lysate-Abcam, cat no. Ab29889.

\section{Gene promoter assays}

The $\mathrm{CpG}$ assays were designed using the Pyromark $\mathrm{CpG}$ software (Qiagen), and the genomic sequences were extracted from the USCS genome browser at www.genome.uscs.edu [55]. The CpGs were identified from the promoter region of each of the target gene. The promoter regions were identified from sequences up to $500 \mathrm{bp}$ upstream of the transcription start sites (TSS) (Table 3). To address epigenetic events associated with fetal growth disorders, we analysed CpG methylation at three sites in the IGF1, IGFBP1 and IGFBP2 promoter

Table 3 Localisation of the CpG sites in the genome

\begin{tabular}{|c|c|c|c|c|c|}
\hline Gene & CpG number & CpG location & Transcription start site (TSS) & Forward primer & Reverse primer (biotinylated) \\
\hline IGF1 & 1 & $\begin{array}{l}\text { Chr12: } \\
-102874567\end{array}$ & 102874323 & GATAGGAAATAGTTGGGGGAATATTTGT & AATCTACTTTACCCCAATCACTTCAA \\
\hline IGF1 & 2 & $\begin{array}{l}\text { Chr12: } \\
-102874689\end{array}$ & 102874323 & GATAGGAAATAGTTGGGGGAATATTTGT & AATCTACTTTACCCCAATCACTTCAA \\
\hline IGF1 & 3 & $\begin{array}{l}\text { Chr12: } \\
-102874755\end{array}$ & 102874323 & GATAGGAAATAGTTGGGGGAATATTTGT & AATCTACTTTACCCCAATCACTTCAA \\
\hline IGFBP1 & 1 & Chr7: 45927583 & 45928093 & TTGAGTAGGGTITTGGGTGTATTAGTAA & AACCCAAACTCTAAACAAATAATAAT \\
\hline IGFBP1 & 2 & Chr7: 45927579 & 45928093 & TTGAGTAGGGTTITGGGTGTATTAGTAA & AACCCAAACTCTAAACAAATAATAAT \\
\hline IGFBP1 & 3 & Chr7: 45927575 & 45928093 & TTGAGTAGGGTITTGGGTGTATTAGTAA & AACCCAAACTCTAAACAAATAATAAT \\
\hline IGFBP2 & 9 & Chr2:217497928 & 217498172 & TGGGGGTTAAGGGTGTTAAG & СTAACCCCTAAAAAACACAAAAAACAT \\
\hline IGFBP2 & 10 & Chr2:217497846 & 217498172 & TGGGGGTITAGGGTGTTAAG & СTAACCCCTAAAAAACACAAAAAACAT \\
\hline IGFBP2 & 11 & Chr2:217497740 & 217498172 & TGGGGGTTTAGGGTGTTAAG & CTAACCCCTAAAAAACACAAAAAACAT \\
\hline IGFBP3 & 46 & Chr7: -45960433 & 45960866 & AGAAGTAGGGGTGGTTAAGGATA & AAACCCTATATACCAATTTCCC \\
\hline IGFBP3 & 47 & Chr7: -45960418 & 45960866 & AGAAGTAGGGGTGGTTAGGATA & AAACCCTATATACCAATTTCCC \\
\hline IGFBP3 & 48 & Chr7: -45960415 & 45960866 & AGAAGTAGGGGTGGTTAAGGATA & AAACCCTATATACCAATTTCCC \\
\hline IGFBP3 & 49 & Chr7:-45960400 & 45960866 & AGAAGTAGGGGTGGTTAGGATA & AAACCCTATATACCAATTTCCC \\
\hline IGFBP3 & 50 & Chr7: -45960394 & 45960866 & AGAAGTAGGGGTGGTTAAGGATA & AAACCCTATATACCAATTTCCC \\
\hline IGFBP4 & 23 & Chr17: 38599317 & 38599681 & GGGGTITAGGTTAAGAGGTATTITGG & ACCCCCAACCCCTTCCCAAAAAT \\
\hline IGFBP4 & 24 & Chr17: 38599314 & 38599681 & GGGGTTAAGGTTAAGAGGTATTITGG & ACCCCCAACCCCTTCCCAAAAAT \\
\hline IGFBP4 & 25 & Chr17: 38599311 & 38599681 & GGGGTITAGGTTTAGAGGTATTITGG & ACCCCCAACCCCTTCCCAAAAAT \\
\hline IGFBP4 & 26 & Chr17: 38599308 & 38599681 & GGGGTTTAGGTTAAGAGGTATTITGG & ACCCCCAACCCCTTCCCAAAAAT \\
\hline IGFBP4 & 27 & Chr17: 38599305 & 38599681 & GGGGTITAGGTTTAGAGGTATTITGG & ACCCCCAACCCCTTCCCAAAAAT \\
\hline IGFBP4 & 28 & Chr17: 38599302 & 38599681 & GGGGTITAGGTTTAGAGGTATTITGG & ACCCCCAACCCCTTCCCAAAAAT \\
\hline IGFBP4 & 29 & Chr17: 38599299 & 38599681 & GGGGTITAGGTTAGAGGTATTITGG & ACCCCCAACCCСТTCCCAAAAAT \\
\hline IGFBP7 & 8 & Chr4: -57976141 & 57975928 & GGAAAGGGGAGAAATTAGAGGG & TCСТACTCCATCCCCAAT \\
\hline IGFBP7 & 9 & Chr4: -57976145 & 57975928 & GGAAAGGGGAGAAATTAGAGGG & TCCTACTCCATCCCCAAT \\
\hline IGFBP7 & 10 & Chr4: -57976152 & 57975928 & GGAAAGGGGAGAAATTAGAGGG & TCCTACTCCATCCCCAAT \\
\hline IGFBP7 & 11 & Chr4: -57976157 & 57975928 & GGAAAGGGGAGAAATTAGAGGG & TCCTACTCCATCCCCAAT \\
\hline IGFBP7 & 12 & Chr4: -57976172 & 57975928 & GGAAAGGGGAGAAATTAGAGGG & TCCTACTCCATCCCCAAT \\
\hline
\end{tabular}


regions, five sites in IGFBP3 and IGFBP7 and seven sites in the IGFBP4 promoter regions (Table 2).

\section{Bisulphite modification}

PureLink Genomic DNA extraction kit (Invitrogen, K1820-02) was used for genomic DNA extraction. EZ DNA Methylation-Gold TM Kit (Zymo Research, Irvine, CA, USA) was used for sodium bisulphite conversion. Approximately $500 \mathrm{ng}$ of genomic DNA was bisulphite modified by incubating at $98{ }^{\circ} \mathrm{C}$ for $10 \mathrm{~min}$ and $64{ }^{\circ} \mathrm{C}$ for $2 \mathrm{~h}$ and $30 \mathrm{~min}$. The product was desulphonated, washed and eluted in $10 \mu \mathrm{l}$ of elution buffer. A $2 \mu \mathrm{l}$ of bisulphite-modified genomic DNA (approximately $500 \mathrm{ng}$ ) was amplified in a PCR mix containing $2 \mu \mathrm{l}$ of forward and reverse primer, $12.5 \mu \mathrm{l}$ of FastStart Taq DNA Polymerase (Lifescience Roche, cat no. 12032929001) and $10.5 \mu \mathrm{l}$ of water. DNA amplification in a thermocycler was performed by following these PCR conditions: 1 cycle at $95{ }^{\circ} \mathrm{C}$ for $6 \mathrm{~min}$, followed by 40 cycles of $95{ }^{\circ} \mathrm{C}$ for $30 \mathrm{~s}$, annealing temperature of 55 to $59{ }^{\circ} \mathrm{C}$ (depending on primer pair) for $30 \mathrm{~s}$ and $72{ }^{\circ} \mathrm{C}$ for $30 \mathrm{~s}$, followed by 1 cycle at $72{ }^{\circ} \mathrm{C}$ for 30 s.

\section{Pyrosequencing}

PyroMark Q96 ID (Qiagen) was used for pyrosequencing analysis. A $10 \mu \mathrm{l}$ of biotinylated DNA obtained with the PyroMark CpG Assays were complexed with $2 \mu \mathrm{l}$ Streptavidin Sepharose High Performance beads (GE Healthcare) in a solution containing $30 \mu \mathrm{l}$ of water and $38 \mu \mathrm{l}$ PyroMark Binding Buffer (Qiagen) per reaction. After vortexing the mixture for $10 \mathrm{~min}$ at room temperature, the beads were washed using the PyroMark Q96 Vacuum Workstation (Qiagen). Beads were then washed in ethanol for $5 \mathrm{~s}$ and placed for $5 \mathrm{~s}$ in $0.2 \mathrm{M} \mathrm{NaOH}$. The beads were further washed for $5 \mathrm{~s}$ in PyroMark Wash Buffer (Qiagen) to ensure that only single-stranded DNA remained attached to the beads. Beads were then placed on a sequencing plate containing $12 \mu \mathrm{l}$ of the appropriate sequencing primers from the PyroMark CpG Assays resuspended in PyroMark Annealing Buffer (Qiagen). The plate was heated for $5 \mathrm{~min}$ at $80^{\circ} \mathrm{C}$ in a heating block and then allowed to cool for $2 \mathrm{~min}$ before loading it on the pyrosequencer. Assay efficiency was validated by 0 and $100 \%$ methylated DNA (CpGenome Universal Methylatated DNA, $10 \mu \mathrm{g}$, Millipore, S7821). The methylation data was analysed by Pyro Q-CpG software 1.0.6.

All the reverse primers were biotinylated. The primers used were IGF1F: 5'-GATAGGAAATAGTTGGGGGAAT ATTTGT-3', IGF1R: 5'-AATCTACTTTACCCCAATCAC TTCAA-3'; IGFBP1F:5'-TTGAGTAGGGTTTTGGGTGT ATTAGTAA-3', IGFBP1R:5'-AACCCAAACTCTAAACA AATAATAAT-3'; IGFBP2F:5'-TGGGGGTTTAGGGTGT TAAG-3', IGFBP2R:5'-CTAACCCCTAAAAAACACAAA AAACAT-3'; IGFBP3F:5'-AGAAGTAGGGGTGGTTTAG
GATA-3', IGFBP3R:5' -AAACCCTATATACCAATTTCCC -3'; IGFBP4F:5'-GGGGTTTAGGTTTAGAGGTATTTTG G-3', IGFBP4R:5' -ACCCCCAACCCCTTCCCAAAAAT-3 '; IGFBP7F:5'-GGAAAGGGGAGAAATTAGAGGG-3', I GFBP7R:5'-TCCTACTCCATCCCCAAT-3'.

\section{Statistical methods}

Kolmogorov-Smirnov test was used to determine normality of the data. Data were expressed as median (interquartile range). Comparison between groups for continuous variables was by Student's $t$ test, Mann-Whitney $U$ test, one-way analysis of variance and Kruskal-Wallis test for normally and not normally distributed data. Categorical data were compared using $x^{2}$ test. Univariate analyses were used to investigate the association between birthweight percentiles and different variables. Statistical analysis was performed using Graphpad Prism 5.0 (Sandiego, CA, USA) and results were considered significant if $p$ value was $<0.05$.

\section{Abbreviations}

BMl: body mass index; CpG: cytosine-phosphate-guanine dinucleotide; IGF1: insulin-like growth factor 1; IGF2: insulin-like growth factor 2; IGFBP17: insulin-like growth factor binding protein 1 to 7; LGA: large for gestational age; mRNA: messenger ribonucleic acid; SEM: standard error of mean; SGA: small for gestational age; TSS: transcription start site.

\section{Competing interests}

The authors declare that they have no competing interests.

\section{Authors' contributions}

AN recruited patients, collected samples and performed the experiments. MS and $\mathrm{VT}$ applied for ethics approval, MS and VT assisted with patient recruitment and MS assisted with statistical analysis. VT and $M C$ designed the experiments, assisted with technical aspects and helped with analysis of the experiments. SHK helped with technical troubleshooting and analysis tools. All authors proofread, contributed and finalised the manuscript.

\section{Acknowledgements}

The study was funded by the Genesis Research Trust and Imperial College London. The authors would like to thank all the women who agreed to take part in the study.

\section{Author details}

${ }^{1}$ Imperial College London, London, UK. ${ }^{2}$ Academic Department of Obstetrics and Gynaecology, Chelsea and Westminster Hospital, London, UK. ${ }^{3}$ Warwick Medical School, University of Warwick, Coventry, UK.

Received: 1 October 2015 Accepted: 19 January 2016 Published: 27 January 2016

References

1. Han VK, Bassett N, Walton J, Challis JR. The expression of insulin-like growth factor (IGF) and IGF-binding protein (IGFBP) genes in the human placenta and membranes: evidence for IGF-IGFBP interactions at the feto-maternal interface. J Clin Endocrinol Metab. 1996;81(7):2680-93.

2. Takeda $Y$, Iwashita M. Role of growth factors on fetal growth and maturation. Ann Acad Med Singapore. 1993;22(2):134-41.

3. Hill DJ, Crace CJ, Strain AJ, Milner RD. Regulation of amino acid uptake and deoxyribonucleic acid synthesis in isolated human fetal fibroblasts and myoblasts: effect of human placental lactogen, somatomedin-C, multiplication-stimulating activity, and insulin. J Clin Endocrinol Metab. 1986;62(4):753-60. 
4. Sferruzzi-Perri A, Owens J, Pringle K, Robinson J, Roberts C. Maternal InsulinLike Growth Factors-I and -II Act via Different Pathways to Promote Fetal Growth. Endocrinology. 2006;147(7):3344-55.

5. Börzsönyi B, Demendi C, Nagy Z, Tóth K, Csanád M, Pajor A, et al. Gene expression patterns of insulin-like growth factor 1, insulin-like growth factor 2 and insulin-like growth factor binding protein 3 in human placenta from pregnancies with intrauterine growth restriction. J Perinat Med. 2011;39(6):701-7.

6. DeChiara TM, Efstratiadis ARE. A growth deficiency phenotype in heterozygous mice carrying an insulin-like growth factor II gene disrupted by targeting. Nature. 1990;345:78-80.

7. Baker J, Liu JP, Robertson EJ, Efstratiadis A. Role of insulin-like growth factors in embryonic and postnatal growth. Cell. 1993;75(1):73-82.

8. Efstratiadis A. Genetics of mouse growth. Int J Dev Biol. 1998;42(7):955-76.

9. Sheikh S, Satoskar P, Bhartiya D. Expression of insulin-like growth factor-I and placental growth hormone mRNA in placentae: a comparison between normal and intrauterine growth retardation pregnancies. Mol Hum Reprod. 2001;7(3):287-92.

10. Iñiguez G, González C, Argandoña F, Kakarieka E, Johnson MC, Cassorla F. Expression and protein content of IGF-I and IGF-I receptor in placentas from small, adequate and large for gestational age newborns. Horm Res Pædiatrics. 2010;73(5):320-7.

11. Abu-Amero SN, Ali Z, Bennett P, Vaughan Jl, Moore GE. Expression of the insulin-like growth factors and their receptors in term placentas: a comparison between normal and IUGR births. Mol Reprod Dev. 1998;49(3):229-35.

12. Calvo MT, Romo A, Gutiérrez JJ, Relaño E, Barrio E, Ferrández Longás A. Study of genetic expression of intrauterine growth factors IGF-I and EGFR in placental tissue from pregnancies with intrauterine growth retardation. J Pediatr Endocrinol Metab. 2004;17 Suppl 3:445-50.

13. Liu YJ, Tsushima T, Onoda N, Minei S, Sanaka M, Nagashima T, et al. Expression of messenger RNA of insulin-like growth factors (IGFs) and IGF binding proteins (IGFBP1-6) in placenta of normal and diabetic pregnancy. Endocr J. 1996;43(Suppl):S89-91.

14. Demendi C, Börzsönyi B, Nagy ZB, Rigó J, Pajor A, Joó JG. Gene expression patterns of insulin-like growth factor 1, 2 (IGF-1, IGF-2) and insulin-like growth factor binding protein 3 (IGFBP-3) in human placenta from preterm deliveries: influence of additional factors. Eur J Obstet Gynecol Reprod Biol. 2012;160(1):40-4.

15. Gratton RJ, Asano H, Han VKM. The regional expression of insulin-like growth factor II (IGF-II) and insulin-like growth factor binding protein-1 (IGFBP-1) in the placentae of women with pre-eclampsia. Placenta. 2002;23(4):303-10.

16. Chowen JA, Evain-Brion D, Pozo J, Alsat E, García-Segura LM, Argente J. Decreased expression of placental growth hormone in intrauterine growth retardation. Pediatr Res. 1996;39(4 Pt 1):736-9.

17. Rosenfeld R. The IGFBP superfamily. Endocr Rev. 1999;20(6):761-87.

18. Oh Y, Müller HL, Lee DY, Fielder PJ, Rosenfeld RG. Characterization of the affinities of insulin-like growth factor (IGF)-binding proteins 1-4 for IGF-I, IGF-II, IGF-I/insulin hybrid, and IGF-I analogs. Endocrinology. 1993;132(3): 1337-44.

19. Jones Jl, Clemmons DR. Insulin-like growth factors and their binding proteins: biological actions. Endocr Rev. 1995;16(1):3-34.

20. Lassarre C, Binoux M. Insulin-like growth factor binding protein-3 is functionally altered in pregnancy plasma. Endocrinology. 1994;134(3):1254-62.

21. Sakai K, Iwashita M, Takeda Y. Profiles of insulin-like growth factor binding proteins and the protease activity in the maternal circulation and its local regulation between placenta and decidua. Endocr J. 1997;44(3):409-17.

22. Howell RJ, Perry LA, Choglay NS, Bohn H, Chard T. Placental protein 12 (PP12): a new test for the prediction of the small-for-gestational-age infant. Br J Obstet Gynaecol. 1985;92(11):1141-4.

23. Forbes $K$, Westwood M. The IGF axis and placental function. a mini review. Horm Res. 2008;69(3):129-37.

24. Gama-Sosa MA, Wang RYH, Kuo KC, Gehrke CW, Ehrlich M. The 5methylcytosine content of highly repeated sequences in human DNA Nucleic Acids Res. 1983;11:3087-95

25. Perrin D, Ballestar E, Fraga MF, Frappart L, Esteller M, Guerin J-F, et al. Specific hypermethylation of LINE-1 elements during abnormal overgrowth and differentiation of human placenta. Oncogene. 2007;26:2518-24.

26. Christensen BC, Houseman EA, Marsit CJ, Zheng S, Wrensch MR, Wiemels JL, et al. Aging and environmental exposures alter tissue-specific DNA methylation dependent upon CPG island context. PLoS Genet. 2009;5(8):1-13.

27. Coan PM, Burton GJ, Ferguson-Smith AC. Imprinted genes in the placenta-a review. Placenta. 2005;26(Suppl A):S10-20.
28. Hemberger M. Epigenetic landscape required for placental development. Cell Mol Life Sci. 2007;64(18):2422-36.

29. Ferguson-Smith AC, Moore T, Detmar J, Lewis A, Hemberger M, Jammes H, et al. Epigenetics and Imprinting of the Trophoblast - A Workshop Report. Placenta. 2006;27:122-6.

30. Constância M, Kelsey G, Reik W. Resourceful imprinting. Nature. 2004;432:53-7.

31. Hanson MA, Gluckman PD. Developmental origins of health and disease: new insights. Basic Clin Pharmacol Toxicol. 2008;102:90-3.

32. Tycko B, Morison IM. Physiological functions of imprinted genes. J Cell Physiol. 2002;192(3):245-58.

33. Reik W, Constância M, Fowden A, Anderson N, Dean W, Ferguson-Smith A, et al. Regulation of supply and demand for maternal nutrients in mammals by imprinted genes. J Physiol. 2003;547:35-44.

34. Maccani MMC. Epigenetics in the Placenta. Am J Reprod Immunol. 2009; 62(2):78.

35. McMinn J, Wei M, Schupf N, Cusmai J, Johnson EB, Smith AC, et al, Unbalanced placental expression of imprinted genes in human intrauterine growth restriction. Placenta. 2006;27(6-7):540-9.

36. Serman L, Vlahović M, Sijan M, Bulić-Jakus F, Serman A, Sincić N, et al. The impact of 5-azacytidine on placental weight, glycoprotein pattern and proliferating cell nuclear antigen expression in rat placenta. Placenta. 2007;28(8-9):803-11.

37. Koutsaki M, Sifakis S, Zaravinos A, Koutroulakis D, Koukoura O, Spandidos D. Decreased placental expression of hPGH, IGF-I and IGFBP-1 in pregnancies complicated by fetal growth restriction. Growth Horm IGF Res. 2011;21(1):31-6.

38. Street ME, Seghini $P$, Ziveri MA, Fieni S, Volta C, Neri TM, et al. Interleukin-6 and insulin-like growth factor system relationships and differences in the human placenta and fetus from the 35th week of gestation. Growth Horm IGF Res. 2006;16(5-6):365-72.

39. Giudice LC, de Zegher F, Gargosky SE, Dsupin BA, de las Fuentes L, Crystal RA, et al. Insulin-like growth factors and their binding proteins in the term and preterm human fetus and neonate with normal and extremes of intrauterine growth. J Clin Endocrinol Metab. 1995:80(5):1548-55.

40. Leger J, Oury JF, Noel M, Baron S, Benali K, Blot P, et al. Growth factors and intrauterine growth retardation. I. Serum growth hormone, insulin-like growth factor (IGF)-I, IGF-II, and IGF binding protein 3 levels in normally grown and growth-retarded human fetuses during the second half of gestation. Paediatric Res. 1996;40(1):94-100.

41. Spencer J, Chang TC, Jones J, Robson SC, Preece M. Third trimester fetal growth and umbilical venous blood concentrations of IGF-1, IGFBP-1, and growth hormone at term. Arch Dis Child Fetal Neonatal Ed. 1995;73(2):F87-90.

42. Van Vliet J, Oates NA, Whitelaw E. Epigenetic mechanisms in the context of complex diseases. Cell Mol Life Sci. 2007;64:1531-8.

43. Abdolmaleky HM, Cheng KH, Faraone SV, Wilcox M, Glatt SJ, Gao F, et al. Hypomethylation of MB-COMT promoter is a major risk factor for schizophrenia and bipolar disorder. Hum Mol Genet. 2006;15(21):3132-45.

44. Zhang J, Wu K, Xu X, Liu Z, Lin C, Wang Y, et al. Correlation of insulin-like growth factor 1 expression in placenta with DNA methylation and fetal macrosomia. Zhonghua Yi Xue Yi Chuan Xue Za Zhi. 2015;32(1):36-9.

45. Apostolidou S, Abu-Amero S, O'Donoghue K, Frost J, Olafsdottir O, Chavele $\mathrm{KM}$, et al. Elevated placental expression of the imprinted PHLDA2 gene is associated with low birth weight. J Mol Med. 2007;85(4):379-87.

46. Verhaeghe J, Van Bree R, Van Herck E, Laureys J, Bouillon R, Van Assche FA. C-peptide, insulin-like growth factors I and II, and insulin-like growth factor binding protein-1 in umbilical cord serum: correlations with birth weight. Am J Obstet Gynecol. 1993;169(1):89-97.

47. De Zegher F, Francois I, Van Helvoirt M, Van Den Berghe G. Clinical review 89: Small as fetus and short as child - From endogenous to exogenous growth hormone. J Clin Endocrinol Metab. 1997;82(7):2021-6.

48. Meio B. Reduction of IGF-binding protein-3 as a potential marker of intrauterine growth restriction. J Perinat Med. 2009;37(6):689-93.

49. Han VK, Carter AM. Spatial and temporal patterns of expression of messenger RNA for insulin-like growth factors and their binding proteins in the placenta of man and laboratory animals. Placenta. 2000;21(4):289-305.

50. Magalhães HR, Leite SB, Paz CC, Duarte G, Ramos ES. Placental hydroxymethylation vs methylation at the imprinting control region 2 on chromosome 11p15.5. Braz J Med Biol Res. 2013:46:916.

51. Li W, Liu M. Distribution of 5-Hydroxymethylcytosine in Different Human Tissues. J Nucleic Acids. 2011;2011:1-5.

52. Piyasena C, Reynolds RM, Khulan B, Seckl JR, Menon G, Drake AJ. Placental 5-methylcytosine and 5-hydroxymethylcytosine patterns associate with size at birth. Epigenetics. 2015;10(8):692-7. 
53. Chen $\mathrm{H}$, Lin B, Chen CL, Johnson PF, Chou JY. Role of the transcription factor C/EBP beta in expression of a rat pregnancy-specific glycoprotein gene. DNA Cell Biol. 1995;14(8):681-8.

54. Hubbard T, Barker D, Birney E, Cameron G, Chen Y, Clark L, et al. The Ensembl genome database project. Nucleic Acisd Res. 2002;30(1):38-41.

55. James Kent W, Sugnet CW, Furey TS, Roskin KM, Pringle TH, et al. The human genome browser at UCSC. Genome Res. 2002;12(6):996-1006.

Submit your next manuscript to BioMed Central and we will help you at every step:

- We accept pre-submission inquiries

- Our selector tool helps you to find the most relevant journal

- We provide round the clock customer support

- Convenient online submission

- Thorough peer review

- Inclusion in PubMed and all major indexing services

- Maximum visibility for your research

Submit your manuscript at www.biomedcentral.com/submit 